\title{
2019年総合大会の開催地から 高田馬場・西早稲田エリア
}

齋藤 恵 (早稲田大学)

2 019 年の総合大会は 2019 年 3 月 19 日から 22 日までの 4 日間の日程で早稲田大学・西早稲田キャ ンパスにて開催されます. 今大会は高田馬場, 西早稲田 という首都圏でも特にアクセスが便利な場所ですので首 都圏の皆様はもちろん, 遠方の皆様にもお気軽に御来場 頂き，たくさんの方々に今大会を楽しんで頂けたらと思っ ています。

初めに, 少し今大会の告知を致します. まずは今回の 目玉の一つである，全ソサイエティ合同で行う懇親会・ Welcome Partyは, 3 月 19 日 $17: 30 \sim 20: 00$ (受付開 始：17:00）に 63 号館 1 階 ロームスクエアにて無料 で行います. 今大会では懇親会とWelcome Party を合 同で行うことにより，より多くの方々に御参加頂けるか と思います．参加費は無料で事前登録も不要, そしてお いしいお酒も出そうなので是非とも皆様御参加下さい ね. 皆様が留親会・Welcome Party を楽しんで頂けた らとてもうれしいです.

また, 今回のプレナリーセッションでは, 情報 $\times$ 政治・ 経済（行政, 介護, 社会の分析等）といった他分野か らの多角的な視点での複数の講演を予定しており, 情報 分野の社会へのますますの広がりやその重要性が実感 できる内容となっています. また, いずれの講演も女性 の登壇を予定, 女性の活躍を感じさせるセッションとな りそうです．女性の活躍や情報の社会への広がりといっ た, 未来へのエネルギーあふれるセッションを準備して おりますので是非多くの方々の御来場をお待ちしてい ます.

さて, 本稿では「2019 年総合大会の開催地から」と いうことで, 会場である早稲田大学・西早稲田キャンパ スの周辺の魅力を簡単に紹介させて頂きます.

高田馬場といえば学生街を連想される方も多くい らっしゃるかと思います．そのとおり，高田馬場エリア はいつも学生がたくさんいる活気のある街で, 若くて元 気な学生のために 安くてボリューム満点, そしておい
しいお店が数多くあります。 また, 高田馬場はラーメン の「激戦区」とも言われており, 早稲田通りを少し歩い てみるだけで，ラーメン店が非常に多いことが分かりま す.一方で, 実は高田馬場はミャンマー料理やタイ料理 といったアジア料理店の宝庫でもあり, 本格エスニック を味わってみるのもよいですね. いろいろな味わいのあ る高田馬場で, 是非皆様も高田馬場ならではのお気に入 りの味を見付けてみて下さいね.

元気な学生街というイメージが強い高田馬場ですが, それだけではありません，実は，自然豊かなスポットや 歴史や文化を感じられる場所も数多くあります．西早稲 田キャンパスから徒歩 10 分ほどの戸山公園には箱根山 という山があり, 山手線内で一番標高の高い山として親 しまれています．とはいえ標高 $44.6 \mathrm{~m}$ ですので，気軽 に散歩気分でプチ登山を楽しむことができます.

また, 西早稲田キャンパスから徒歩 20 分ほどの早大 早稲田キャンパスには早大の象徴である大隈講堂や大隈 重信像があり，早大を訪れる方に人気のスポットとなっ ています．更に早稲田キャンパスの付近には関口芭蕉庵 という松尾芭蕉の住居跡や庭園といった史跡や, 夏目漱 石ゆかりのスポット（夏目坂, 夏目漱石誕生之地の碑, 新宿区夏目漱石記念館）もあり, 散歩と一緒に早稲田エ リアの歴史や文化に触れてみるのもよいですね.

また, 西早稲田キャンパスの最寄り駅である西早稲田 駅からは, 新宿御苑や東京都庁展望室, 明治神宮へのア クセスが 1 本と非常に便利ですので, 少し足を延ばし た周辺エリアの散策や観光も楽しいかもしれません.

「早大理エキャンパス」である西早稲田キャンパスの 周辺は様々な魅力的なスポットがあります. 是非総合大 会では充実した講演や最新の技術情報についての議論・ 情報交換をお楽しみ頂き, また, 早稲田・高田馬場エリ アの魅力にも触れてみて下さいね，それでは，早稲田大 学・西早稲田キャンパスでお会いできることを実行委員 一同心よりお待ちしています!

\section{0}

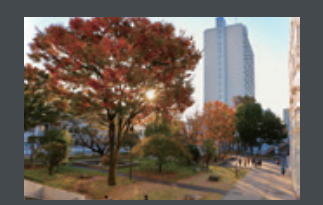

図 1 西早稲田キャンパス

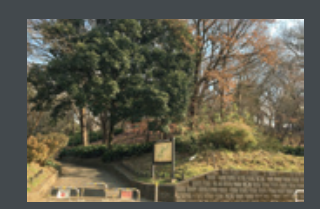

図 2 箱根山

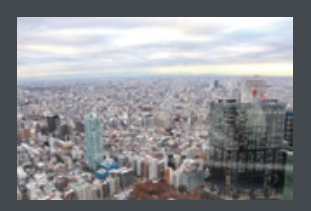

図 3 都庁展望室から 